\title{
A PORNOGRAFIA É UM MORTO-VIVO?
}

Jorge Leite Jr. ${ }^{1}$

\begin{abstract}
Resumo: Talvez uma das características mais notáveis da produção audiovisual conhecida como pornografia seja sua infinita capacidade de parodiar. De desenhos animados a canções, de obras literárias a produções cinematográficas, o gênero pornográfico parece ter como um de seus principais alimentos os outros tipos de "gêneros": artísticos e sexuais. Desta forma, aproveitando o sucesso midiático de um dos mais divulgados monstros contemporâneos - o zumbi -, a pornografia também incorpora este curioso ser que representa um morto que continua insistentemente atuando no mundo dos vivos. $O$ objetivo deste trabalho é apresentar uma reflexão sobre filmes pornôs com zumbis, indagando o quanto a própria pornografia pode ser vista como um gênero que vive de devorar outros gêneros (artísticos) e, principalmente, o quanto a produção pornô em seu viés mainstream reproduz papéis de gênero (sexual) tradicionais que historicamente poderiam já estar mortos e enterrados, mas que continuam atuando insistentemente em nosso cotidiano.
\end{abstract}

Palavras-chave: Pornografia. Gênero. Horror. Grotesco. Zumbis.

Talvez uma das características mais notáveis da produção audiovisual conhecida como pornografia seja sua infinita capacidade de parodiar. De desenhos animados a canções, de obras literárias a produções cinematográficas, o gênero pornográfico parece ter como um de seus principais alimentos os outros tipos de "gêneros": artísticos e sexuais (ABREU, 1996; DIAZ-BENÍTEZ, 2010; WILLIAMS, 2004; SAEZ, 2003). Desta forma, aproveitando o sucesso midiático de um dos mais divulgados monstros contemporâneos - o zumbi -, a pornografia também incorpora este curioso ser que representa um morto que continua insistentemente andando e agindo no mundo dos vivos, além de devorar outros humanos.

O objetivo deste artigo é apresentar uma reflexão sobre filmes pornôs com zumbis, indagando o quanto a própria pornografia pode ser vista como este morto-vivo, ou seja, como um gênero que vive de devorar outros gêneros (artísticos) e, principalmente, o quanto a produção pornô em seu viés mainstream, reproduz papéis de gênero (sexual) tradicionais que historicamente poderiam já estar mortos e enterrados, mas que continuam operando assustadoramente em nosso cotidiano. Chamo aqui de pornografia mainstream aquela que apresenta a ideia de "prática sexual" como um corpo (de homem ou mulher) masculinizado e visto como "ativo" dominando e, principalmente, penetrando (seja em qual orifício for) um corpo (de homem ou mulher) feminilizado e visto como "passivo", tanto em produções heterossexuais quanto em homossexuais ${ }^{2}$. Para esta reflexão, utilizarei os conceitos de paródia e estética do grotesco que, conforme os dois mais importantes pesquisadores deste último tema

\footnotetext{
${ }^{1}$ Professor do Departamento de Sociologia da Universidade Federal de São Carlos (UFSCar). E-mail: jcabelo@uol.com.br

${ }^{2}$ Exemplos destes filmes podem ser encontrados gratuitamente em sites como http://www.xtube.com/; http://www.pornotubevideos.net/; $\quad$ http://www.redtube.com/; $\quad$ http://www.youporn.com/; http://www.porn.com/
} 
(BAKHTIN, 2010; KAYSER, 1986), possui como algumas das características principais o exagero, a desarmonia, o desequilíbrio, a desproporção e o excesso, evocando tanto o riso quanto o desconforto, a repulsa e a curiosidade - elementos estes fundamentais tanto para o universo audiovisual do pornô quanto do horror e do humor.

\title{
A PARÓDIA E O GROTESCO
}

Seja na literatura especificamente ou na arte em geral, a paródia é uma técnica e uma forma artística tão estudada quanto, muitas vezes, desqualificada. Tanto em Bakhtin $(1981 ; 2010)$, uma das principais referências analíticas sobre o tema, quanto em muitas das pesquisas e reflexões que nele se baseiam - ou dele partem e dialogam (AUGUSTO, 1989; ALAVARCE, 2009; SANT'ANNA, 1988) - e mesmo nos trabalhos que questionam e ampliam esta noção (HUTCHEON, 1993), não existe uma definição universal e definitiva de paródia. No entanto, todos estes autores aqui citados concordam em um ponto: a paródia é uma forma de imitação que visa provocar um estranhamento no receptor da obra paródica com relação à obra imitada. Nos termos de Sérgio Augusto (1989, p. 150), "A paródia é uma forma de imitação irônica e deformante, inversora de valores, uma repetição com distanciamento crítico”. Embora para Hutcheon (1993) a paródia nem sempre ridicularize, rebaixe ou mesmo inverta os valores daquilo que é parodiado (embora faça isso na grande maioria das vezes), podendo mesmo ser elogiosa, ela sempre provoca algum grau de reflexão crítica.

Para isso, a paródia necessita de um modelo a ser imitado, e que, para seu máximo efeito, este modelo tem que ser conhecido e reconhecido pelo receptor, desmontando assim os ideais universais e atemporais que podem estar como pano de fundo do trabalho parodiado, ao mesmo tempo em que o historiciza, provocando tanto a reflexão quanto o "paradoxo da paródia", conforme Alavarce (2009, p. 67):

\begin{abstract}
Uma vez considerada a paródia como uma categoria que possibilita a revisão crítica de discursos históricos e literários, promovendo, consequentemente, a manutenção desses mesmos discursos, chega-se a uma interessante contradição: a paródia, ao mesmo tempo que "põe em xeque" alguns modelos, transgredindo-os, acaba reforçando, legitimando tais modelos.
\end{abstract}

Esta polêmica sobre a "transgressão autorizada" e a "autoridade transgressiva" é uma constante, seja nas reflexões sobre a paródia e a lógica do mundo às avessas - ou a "carnavalização" do mundo, conforme Bakhtin (1981; 2010) -, seja também nos debates sobre pornografia.

Talvez o tipo de humor mais encontrado na pornografia seja a paródia ${ }^{3}$. Desde o começo do século XX, em filmes como $O$ gabinete da dra. Caligari ${ }^{4}$, até o início do

\footnotetext{
${ }^{3}$ Existem inclusive sites de vídeos pornôs que apresentam apenas paródias, como o Sleazy dream - free parody porn tube. Disponível em: http:/www.sleazydream.com/Parody-tube/13884/1/p0/

${ }^{4}$ Coleção 100 anos de erotismo no cinema, vol 2. Sem a cidade, sem a data.
} 
XXI, com This is ain't AVATAR XXX - this is a parody ${ }^{5}$, passando por literalmente milhares de produções do tipo, principalmente do cinema estadunidense, a paródia é um elemento constante e seguro da união entre riso, humor e sexo. Na maioria destes filmes, o que fica explícito é a capacidade do pornô de penetrar em todos os temas, gêneros e, principalmente, títulos. Como Linda Williams (2004) e Nuno Abreu (1996) notaram, a pornografia parece ser um líquido que se adapta a qualquer recipiente, ou seja, ela pode imitar tudo e adotar infinitos formatos, transformando qualquer obra em uma versão pornô.

O importante para este artigo é que, neste sentido, a pornografia pode ser pensada não apenas como um tipo de produção que faz paródias, mas ela mesma como uma paródia, uma ridicularização exagerada e caricata de uma sexualidade imaginada como "normal", "comum" ou, principalmente, "ideal", mesmo não sendo essa sua intenção original. Ou seja, quando ela parodia um filme não pornográfico, ao reproduzir na versão pornô mainstream deste filme todos os clichês e estereótipos do que se imagina que é (ou deve ser) a prática sexual (principalmente a noção de um corpo viril e ativo que predominantemente penetra em um corpo oferecido e passivo), este hiperbolismo pode tanto reforçar estas imagens e ideais quanto torná-las grotescas ou mesmo risíveis, em uma inversão do próprio paradoxo da paródia. Conforme Sant'Anna (1988, p. 32), "A paródia é como a lente: exagera os detalhes de tal modo que pode converter uma parte do elemento focado num elemento dominante, invertendo, portanto, a parte pelo todo, como se faz na charge a na caricatura".

Ora, é justamente este caráter exagerado, deformante e metonímico (parte pelo todo) da pornografia mainstream que talvez mais caracterize sua produção audiovisual, apresentando um modelo de imagens típicas daquilo que é conhecido como "estética do grotesco".

Conforme Sodré e Paiva (2002), o grotesco surge como uma categoria estética independente apenas no século XIX, quando o escritor Vitor Hugo lança em 1827 seu livro Cromwell, cujo prefácio - que ficará conhecido como Do grotesco e do sublime (HUGO, 2002) - será a base conceitual desta nova estética. Pertencente ao movimento artístico mais amplo do Romantismo, Hugo cria o drama romântico, que seria a união da tragédia com a comédia, gerando o grotesco e o sublime: o grotesco então "de um lado, cria o disforme e o horrível; do outro, o cômico e o bufo" (HUGO, 2002, p. 30), e torna-se assim uma maneira de apresentar o sublime e o belo através do degradado e do disforme. Estas noções são fundamentais para ajudar a estabelecer o rompimento ético/ estético/ político e erótico da burguesia com o Antigo Regime através da separação conceitual entre os ideais de "aparência" e uma pressuposta "essência". Esta noção de grotesco do século XIX possui forte relação com o riso, visando ressaltar, por contraste, o sofrimento (SODRÉ e PAIVA, 2002), em especial do ponto de vista burguês (BAKHTIN, 2010).

O importante da criação de uma categoria estética autônoma, agora genericamente conhecida como "estética do grotesco", é a afirmação de sua independência com relação

\footnotetext{
5 Dir: Axel Braun, EUA, 2010. Este é um pornô em 3D, como seu original, o filme Avatar (James Cameron, EUA/Reino Unido, 2009).
} 
a outras regras estéticas. Ou seja, o grotesco tem que ser analisado a partir de seus próprios referenciais e valores, e não por elementos valorativos de outras categorias estéticas.

Conforme os dois autores mais clássicos sobre o tema, Mikhail Bakhtin (2010) que estudou o "realismo grotesco", as festas e ritos de inversão social (a carnavalização) e a importância do "baixo corporal" nas manifestações populares artísticas e festivas durante a Idade Média e o Renascimento (trabalho escrito em 1940 e publicado em 1965) - e Wolfgang Kayser (1986) - que estudou o histórico do conceito e dos estilos artísticos considerados grotescos tanto na literatura quanto nas artes visuais e arquitetura (em seu livro lançado em 1957) -, alguns elementos podem ser citados como característicos da estética do grotesco: a mistura corporal entre os seres e/ou reinos da natureza; a monstruosidade; a deformidade; a desproporção; as medidas absurdas e, principalmente, a inversão das hierarquias estabelecidas.

O termo "grotesco" surge na Itália (no século XV), no coração do Renascimento, representando o oposto das ideias das artes renascentistas em desenvolvimento e que prezavam o equilíbrio, a harmonia e a proporção.

\footnotetext{
Na palavra grottesco, como designação de uma determinada arte ornamental, estimulada pela Antiguidade, havia para a Renascença não apenas algo lúdico e alegre, leve e fantasioso, mas, concomitantemente, algo angustiante e sinistro em face de um mundo em que as ordenações de nossa realidade estavam suspensas (KAYSER, 1986, p. 20).
}

Quanto mais historicamente vai se formando a idéia de um "gosto" ideal, refinado e educado, voltado ao "belo", também vai se formando como oposto constitutivo a noção de um contragosto, ou "desgosto" (SODRÉ e PAIVA, 2002), voltado a tudo o que desestabiliza este "belo". O grotesco desenvolve-se então como duas idéias interligadas: ora como sinistro, estranho, desagradável e um tanto quanto perigoso, ora como ridículo, engraçado e desprezível. Desta forma, o grotesco evoca medo e riso, criando uma forte associação com o proibido e suas relações com sexo, sangue, excrementos, "deformidades" e as perigosas transgressões de uma pressuposta ordem estabelecida.

Ao evocar a desordem, a desarmonia, o desequilíbrio e o movimento, principalmente através do hiperbolismo, do excesso, da proximidade exagerada (como nos super closes) e da combinação inusitada e deformante entre categorias (animal/ vegetal/ mineral/ divino/ demoníaco/ humano; dentro/ fora; claro/ escuro; vida/ morte entre várias), este discurso estético visa causar estranheza, repulsa, medo; e também riso, curiosidade, desejo e prazer: o prazer da confusão de valores, da transgressão - por isso comumente um prazer mal visto e considerado potencialmente perigoso.

Isso fica claro nas representações do corpo humano e do sexo, conforme analisado por Bakhtin (2010) sobre a Idade Média e Renascimento. No "realismo grotesco", o que importa é mostrar os corpos em constante transformação, nunca acabados ou definitivos. Daí a importância das protuberâncias e orifícios do corpo, com seus jorros de fluidos, gases e sons, expressando a troca com o mundo e a permanente mudança de nossas formas físicas. Tudo o que é ideal, sublime (ou sublimado) e compreendido como espiritual é literalmente encarnado. 
O princípio material e corporal aparece sob a forma universal, festiva e utópica. O cósmico, o social e o corporal estão ligados indissoluvelmente numa totalidade viva e indivisível. [...] O traço marcante do realismo grotesco é o rebaixamento, isto é, a transferência ao plano material e corporal [...] de tudo o que é elevado, espiritual, ideal e abstrato (BAKHTIN, 2010, p. 17).

O chamado "baixo corporal" (principalmente as vísceras, ventre, genitais, nádegas e pés) adquire o protagonismo da expressão do sujeito e tudo que é pensado como superior torna-se corporificado pelo seu rebaixamento, apresentando na carne o "mundo às avessas" das festas populares de inversão social. Daí a importante imagem medieval (e ainda tão presente nas obras pornôs ou de horror) que apresentam a inversão rosto/ ânus, mostrando muitas vezes, entre e dentro das nádegas, uma outra face para o ser humano, ridicularizando a expressão máxima da individualidade burguesa e da religiosidade cristã.

É importante lembrar que ao analisar as festas populares e carnavalescas da Idade Média, Bakhtin ressalta a diferença entre o grotesco popular e o burguês, que surge a partir do século XVII e foi teorizado por Victor Hugo, como vimos: o primeiro tipo possui sua fonte de compreensão do mundo através do corpo, do rebaixamento dos valores elevados, da festa, da relação com os outros corpos e pessoas e da coletividade das críticas. Já o "grotesco de câmara" é uma expressão da individualidade burguesa, que passa mais pelos sentimentos de nojo, desespero e piedade causados pela visão do corpo disforme, da melancolia intelectual e solitária e da pessoalidade dos ataques que visam principalmente destruir seu alvo. Apesar de alguns estudiosos ressaltarem que a vida medieval não era assim tão "divertida" e a violência opressiva era uma constante, pois "não apenas alegria e humor, não só festa e descanso da população, mas também crueldade, ódio e massacre poderiam ser os ingredientes do carnaval " (GUREVICH, 2000, p. 86), vale ressaltar do trabalho de Bakhtin alguns elementos que são fundamentais para este artigo: a ideia do riso paródico como elemento desestabilizador, o corpo como fonte não apenas de diversão, mas, principalmente, de mudança, alteração e/ ou "deformação" de uma imaginada ordem biológica e social.

Sodré e Paiva (2002) afirmam que o grotesco foi a categoria estética que mais influenciou a cultura artística e midiática do século XX. Da mesma forma, Hutcheon (1993) declara que a paródia é um dos elementos fundamentais e estruturantes não só do modernismo, mas, principalmente, do pós-modernismo ${ }^{6}$. Neste sentido, se genericamente pudermos pensar o grotesco como uma forma e a paródia como um efeito, não é coincidência que estes são os elementos que, creio, vão influenciar diretamente a representação audiovisual da sexualidade que também mais se desenvolveu no século XX: a pornografia.

Ainda conforme Bakhtin,

[o grotesco] só se interessa pelos olhos arregalados, pois interessa-se por tudo o que sai, procura sair, ultrapassar o corpo, tudo o que procura escapar-lhe. Assim, todas as excrescências e ramificações têm nele um valor especial, tudo o que em suma prolonga o corpo, reúne-o aos outros corpos ou ao mundo não corporal. [...] No entanto para o grotesco, a boca é a parte mais marcante do rosto. A boca domina. O rosto grotesco se

\footnotetext{
${ }^{6}$ Dias e Lyra, já em 1980, também percebiam esta influência da paródia na literatura moderna em geral e na cultura brasileira em particular.
} 
resume afinal a uma boca escancarada, e todo o resto só serve para emoldurar essa boca, esse abismo corporal escancarado e devorador (BAKHTIN, 2010, p. 276, grifos do autor).

Ora, esta ideia de um "abismo corporal escancarado", seja referente a uma boca (como as gárgulas), aos orifícios genitais (como na pornografia), ou aos ferimentos e mutilações do corpo, expondo suas entranhas, além de ser uma imagem tipicamente grotesca (e pornográfica), também evoca um dos mais importantes monstros midiáticos do início do século XXI: o zumbi.

\section{OS ZUMBIS7}

Segundo o historiador das religiões e filósofo romeno Mircea Eliade, alguns temas associados ao universo da religiosidade tradicional e do mito parecem ser constantes em várias culturas: a dualidade sagrado-profano, o desenrolar do tempo visto como algo cíclico (o "eterno retorno") e a importância de um espaço físico onde tanto as narrativas sócio-culturais quanto a realidade material se originam, o axis mundi, ou eixo do mundo (ELIADE, 1979, 1992). Em suas pesquisas, o autor também analisa um dos mais importantes assuntos relacionados à vida humana: a morte e, consequentemente, o medo de uma morte "incompleta", causadora de desordens e conflitos entre os limiares do mundo dos vivos e dos mortos (ELIADE, 1979). Desta forma, podemos afirmar que a crença em defuntos que transgridem sua condição "ontológica" de mortos insistindo em perturbar o mundo dos viventes, tornando-se assim "mortos-vivos", é algo comum a muitas culturas.

Mas cada cultura e cada época cria seu morto-quase-vivo (ou seus vivos-quasemortos) de acordo com seus referenciais e valores próprios. Através deste monstro que trai um dos tabus sociais mais antigos e firmemente estabelecidos, uma série de valores, conflitos e, principalmente, medos históricos e sociais podem ser reconhecidos. Este parece ser o caso dos zumbis contemporâneos, personagens da cultura do entretenimento que, de origem colonial e religiosa, alcançaram no início do século XXI o status midiático de uma das principais metáforas do caos social (DREZNER, 2011). Seja em filmes, livros, quadrinhos ou videogames (RUSSEL, 2010), os zumbis predominam como o exemplo fantástico e ficcional de um inimigo violento e irracional, numericamente superior, sem o menor traço de sentimentos (e compaixão), devorador literal de vidas e cuja origem é misteriosa e confusa.

Conforme Mary Del Pirore (2000), os primeiros relatos modernos sobre cadáveres que devoravam gente surgem no Leste europeu no século XVIII e vão dar origem ao mito do vampiro. Um dos textos sobre esse tema mais importantes do período citado foi o do monge beneditino Auguste Calmet. Este abade, fortemente influenciado pelo iluminismo, pretendia mostrar que os mortos-vivos não passavam de superstições que afloram em lugares miseráveis com populações ignorantes. Primeiro falando da Hungria e depois comentando brevemente sobre os alemães, o religioso afirma: "é opinião corrente na Alemanha que alguns mortos mastigam e devoram, nas sepulturas, aquilo

\footnotetext{
${ }^{7}$ Para uma análise mais aprofundada sobre a figura do zumbi, ver: Landa, Leite Jr. e Torrano, 2013.
} 
que têm a sua volta, e que se os ouve comer à maneira dos porcos, com algum ruído surdo e quase murmurando e grunhindo" (CALMET, s/d, p. 34). Sobre a maneira de resolver esse problema, de acordo com os crentes, "o único remédio contra essas aparições é decapitar e queimar o corpo desses 'aparecidos"' (CALMET, s/d, p. 26).

Principalmente a partir deste texto (e alguns outros escritos do período menos famosos sobre o tema), nascerá toda uma literatura sobre mortos-vivos sedentos de humanos e, a partir de então, conhecidos como "vampiros" (DEL PRIORI, 2000). No século XX, estas obras se desenvolverão tendo como alguns dos representantes artísticos mais conhecidos o romance Drácula (1897), do escritor irlandês Bram Stoker e, em sua livre adaptação cinematográfica, o filme homônimo do diretor Tod Bowning, lançado em 1931 e tendo o famoso conde sedutor interpretado pelo ator Bela Lugosi. A carga erótica destas duas obras ${ }^{8}$ é patente, transparecendo o quanto a monstruosidade é um tema privilegiado em nossa cultura para a canalização de desejos, práticas e identificações que só podem ser expressas pela lógica do perigo e da violação de tabus 9 .

Contrastando com os tradicionais defuntos mastigadores dos relatos oitocentistas ou aos aristocráticos e eróticos bebedores de sangue inspirados em Drácula, na primeira década do século XXI, os vampiros que fazem sucesso na literatura e no cinema são adolescentes de classe média que desejam casar virgens e não lembram em nada um cadáver ambulante. Com o crepúsculo dos nobres e sensuais mortos-vivos vampiros agora jovens totalmente deserotizados que lutam para serem "felizes no amor burguês" surge o amanhecer das massas putrefatas de mortos-vivos zumbis.

Em 1915, depois de um grande período de instabilidade política e econômica, o Haiti é invadido pelos Estados Unidos sob o pretexto de pacificar os conflitos internos e reorganizar a economia local, controlando política e militarmente o país ${ }^{10}$ (RUSSEL, 2010), que alcançara sua independência em 1804 e tornara-se a primeira república negra da história. Note-se bem: um país, no período, assumidamente racista e segregacionista (EUA), assume o controle militar e administrativo de outro país até então governado e povoado por pessoas negras (Haiti). Neste contexto, o aventureiro e jornalista William Seabrook chega a esta terra em 1928 e, um ano depois, lança o livro A Ilha da magia. Até então, "zumbi" era um termo regional restrito ao caribe.

\footnotetext{
${ }^{8}$ E de toda a literatura gótica do período.

${ }^{9}$ Na passagem do século XIX para o XX, a figura da múmia também contribuiu para o imaginário sobre mortos que saem de suas tumbas (LOUDERMILK, 2003). Mas, apesar de intimamente associado ao colonialismo europeu e de seu caráter de realeza da Antiguidade, este morto-vivo de inspiração egípcia não se desenvolveu com a mesma vitalidade que o vampiro da mesma época. Talvez para o período, a imagem de uma múmia carcomida e abatida, associada a um possível e velado apodrecimento físico, tenha provocado sua falta de sensualidade e o completo distanciamento do universo erótico, tão importante para a literatura de horror da época. Para a pornografia audiovisual contemporânea, as vísceras expostas e o corpo putrefato não são elementos que, a princípio, possam impedir a erotização (assim como esta mesma exposição orgânica não impede a apresentação destas imagens em programas considerados educativos), gerando tanto os crescentes filmes com zumbis excitados quanto os filmes com múmias sexualmente sedentas. Exemplos disso são as obras Mummy X (Giancarlo Candiano, 2005) e Raiders of the lost arse: The mummy's hand (Raging Stallion, 2001).

${ }^{10}$ As tropas norte-americanas se retiram apenas em 1934.
} 
É este texto que vai divulgar massivamente para um público que se considerava moderno, racionalista, urbano e ávido por novidades exóticas, a religião vodu como algo exótico e a figura do zumbi como sendo um infeliz escravo rural morto-vivo (BISHOP, 2008; RUSSEL, 2010). O texto tornou-se um sucesso imediato em vários países ocidentais e iniciou uma crescente busca no mundo do entretenimento por pessoas mortas de culturas e nações subalternas que, através de poderes mágicos e sobrenaturais, permaneciam vivas e mortas ao mesmo tempo.

O título do livro em sua edição em português é $A$ Ilha da magia-fatos e ficção ${ }^{11}$. Sem em nenhum momento deixar claro o que é fato e o que é ficção, o trabalho de Seabrook não é tão sensacionalista quanto foi seu sucesso. Em muitas passagens do texto o autor relativiza o caráter visto como "primitivo" da religião e dos costumes haitianos, comparando-os com os hábitos americanos e europeus, defende a espiritualidade presente no vodu e enaltece tanto o corpo quanto o caráter dos nativos, demonstrando um genuíno carinho e respeito por este povo. Mesmo assim, algumas passagens marcam o forte traço de um olhar superior, como quando fala sobre canibalismo, sacrifícios humanos e, ao final do texto, justifica ambiguamente a invasão norte-americana. Conforme este autor, citando os informantes com quem conversou, o zumbi

era um corpo humano sem alma, morto mas tirado de seu túmulo e animado de uma aparência de vida para fins de feitiçaria; em suma, o zumbi era um morto que podia andar e agir como um ser vivo (SEABROOK, s/d, p. 78).

Ressaltando a ligação fundamental encontrada na lenda entre o zumbi e o trabalho escravo, Seabrook mais à frente narra seu encontro com esses trabalhadores amaldiçoados e infelizes em uma das passagens mais impactantes do livro:

\begin{abstract}
Minha primeira impressão dos três zumbis, que continuavam a trabalhar, foi a de que eles tinham realmente alguma coisa de estranho. Seus gestos eram de autômatos. Não podia ver seus rostos, por estarem próximos ao chão, mas Polynice segurou um deles pelos ombros e pediu que endireitasse os ombros. Dócil como um animal, o homem levantou-se e o que vi então causou-me um choque desagradável. O mais horrível era o olhar, ou melhor, a ausência de olhar. Os olhos estavam mortos, como se fossem cegos, desprovidos de expressão. Não eram olhos de um cego, mas de um morto. Todo o semblante era inexpressivo, incapaz de expressar-se (SEABROOK, s/d, p. 84).
\end{abstract}

Conforme Russel, se referindo ao trabalho de Seabrook e depois à pesquisa desenvolvida pelo etnobiólogo Wade Davis ${ }^{12}$, também no Haiti, "para a maioria dos haitianos, o medo predominante não era o de ser atacado por um zumbi, mas de tornarse um deles" (RUSSEL, 2010, p. 27). Podemos assim perceber o quanto o zumbi

${ }^{11} \mathrm{O}$ título original é apenas The magic island.

12 DAVIS, Wade. A Serpente e o arco-íris. Rio de Janeiro: Jorge Zahar Editor, 1986. Outra característica importante dos trabalhos de Davis foi mostrar a morte como um dado muito mais cultural e social do que biológico. Ao passar pelos rituais de velório e sepultamento, o indivíduo é considerado morto pela comunidade, independente de seu funcionamento biológico. 
"tradicional", ou "haitiano", era associado a um imaginário religioso e colonial ${ }^{13}$. Sua figura evocava o trágico destino de uma morte sem descanso, tornando a pessoa zumbificada um eterno trabalhador escravo, sempre à serviço de seu mestre e senhor, sem desejos, esperanças ou qualquer grau de liberdade.

Em 1968, George Romero lança nos Estados Unidos o filme A Noite dos mortosvivos, obra que vai originar a figura do zumbi contemporâneo: um morto que retorna à vida sem consciência, comumente atacando em grupo e cujo único objetivo é devorar os humanos vivos, transformando aqueles que foram mordidos em novos zumbis. Esta película estabelece inclusive alguns dos principais elementos narrativos que formarão este gênero: imagens diretas e explícitas de mutilação e morte; a constante dúvida sobre a "causa" ou a "origem" destes seres; as pessoas sendo perseguidas e encurraladas (provocando uma sensação de clausura e claustrofobia); o convívio forçado e o consequente conflito entre sujeitos totalmente distintos em vários níveis: social, econômico, cultural e moral; a completa ausência de confiança nas forças estatais e nas instituições públicas (como a polícia ou o governo); a descrença na solidariedade e capacidade de ajuda mútua entre as pessoas e o crescente número de zumbis/ inimigos.

Mas os elementos mais inovadores criados por Romero e que definitivamente rompem a continuidade do zumbi contemporâneo com seu homônimo haitiano são o canibalismo e o contágio. A partir de A Noite dos mortos-vivos, os zumbis se desenvolveram como seres que perseguem as pessoas para devorá-las e que, tendo contato com as secreções, mordidas ou arranhões deles, os humanos estão fatalmente condenados a tornarem-se também um cadáver faminto - em um processo de contaminação bem próximo dos utilizados pelos vampiros, como já visto.

Curiosamente, em nenhum momento deste filme fundante, a palavra "zumbi(s)" é proferida. O termo usado é sempre "mortos-vivos" ou, mais comumente, apenas "mortos". Talvez com isso o diretor já quisesse deixar claro a não relação entre o zumbi haitiano e os defuntos ambulantes contemporâneos ${ }^{14}$. Foram os filmes da década de 70 do século XX em diante que passaram a chamar este ser de "zumbi". Afinal, o cinema foi o grande divulgador deste novo estilo de terror e sua nova personagem monstruosa.

A corporeidade do zumbi contemporâneo é um de seus traços definidores. Sua principal característica não é mais a alma aprisionada e abatida, mas o corpo putrefato e sempre pronto para contaminar e corromper os ideais de saúde física e social. Ora, a

\footnotetext{
13 O Haiti se tornaria na década de 80 o país mais pobre da América Latina. Logo em seguida, os Estados Unidos, nesse período, o culpam pela epidemia de AIDS, mais uma vez associando o "desregramento sexual" dos negros à catástrofe e consequente ruína da civilização branca. Apenas depois de protestos diplomáticos, o Centro de Controle e Prevenção de Doenças (algo próximo ao Ministério da Saúde no Brasil) reviu sua posição desresponsabilizando as pessoas negras haitianas pelo avanço da doença nos EUA. Mesmo assim, fica reforçada a íntima relação entre o Haiti e o perigo do contágio de doenças altamente mortais, sendo este último elemento fundamental para o imaginário do zumbi contemporâneo.

14 Como o próprio Romero afirma, sua grande inspiração para esta obra foi o filme The last man on Earth (Ubaldo Ragona, EUA/Itália, 1965), que conta a história do último sobrevivente humano (Vicent Price) depois que uma epidemia transforma todas as pessoas do planeta em - vampiros! As várias cenas em que estes seres cercam o protagonista em sua casa são o protótipo explícito das cenas de encurralamento dos futuros filmes de zumbis. Este filme, por sua vez, foi a primeira versão filmada do romance de ficção científica I am legend, de 1954, do escritor Richard Matheson.
} 
visão da interioridade do corpo humano é justamente uma das características não apenas do grotesco (ou mesmo do pornográfico), mas da cultura visual e científica de nossa época. Seja com os avanços das tecnologias médicas, com o cinema de horror e suas vísceras expostas, na arte de vanguarda ou na mídia em geral, a imagem do corpo aberto, fragmentado, desmembrado e expondo seu interior é uma constante (MORAES, 2010; ORTEGA, 2013).

\begin{abstract}
Numa cultura na qual a intimidade deixou de ser valorizada e protegida, passando a ser exposta nos mais ínfimos detalhes em reality shows, programas de auditório, diários na Internet e outros teatros do eu contemporâneos, a interioridade visceral revelada pelas novas imagens acompanha esse processo de externalização. Apesar de essas imagens serem tão pessoais e 'íntimas' por pressagiar de maneira tão eficaz nossa condição mortal, estamos nos acostumando à sua difusão e reprodutibilidade (ORTEGA, 2013, p. 91).
\end{abstract}

Talvez a figura tipicamente grotesca do zumbi apresente a maneira como estamos nos adaptando a ver o corpo humano: um agrupamento de vísceras, ossos e secreções cada vez mais expostas. Nesta nova maneira de pensar e representar o corpo, a pele perde sua função de velar pelo encobrimento de seu interior, acabando com o "pudor orgânico" e gerando uma nova "obscenidade", ou seja, colocando em cena o que, até então, esperava-se que estivesse fora de cena: o lado "de dentro" do organismo. Desta forma, percebemos realmente o quanto a estética do grotesco, em seu sentido de exposição do oculto e exaltação do interior orgânico, é estruturante da cultura visual da contemporaneidade.

O filósofo e crítico de cinema Noël Carroll (1999), em seu livro sobre o horror estético, analisa o horror artístico (um sentimento específico de medo e asco que vivenciamos ao apreciar obras que sabemos ser ficção) e as duas características que os monstros destas produções devem ter para gerar este sentimento: eles devem ser vistos como perigosos e repugnantes. "Os objetos do horror artístico são essencialmente ameaçadores e impuros" (CARROLL, 1999, p. 63). "O horror artístico exige uma avaliação tanto da ameaça quanto da repugnância” (CARROLL, 1999, p. 45).

Ora, esses dois elementos são facilmente identificados tanto na personagem do zumbi contemporâneo quanto em muito (mas não na totalidade) da estética do grotesco. Este morto-vivo ameaça não apenas por sua fome insaciável de carne humana e do elemento contagioso de sua condição, mas por estar sempre associado a um colapso estético e civilizacional. Não por acaso, o termo "apocalipse zumbi" é constante em tais obras. Da mesma forma, sua figura visa provocar o nojo e o asco, exatamente algumas das principais características do grotesco, através da exposição do corpo em decomposição. Assim, podemos afirmar que o zumbi contemporâneo representa primeiramente o inumano ou, melhor dizendo, um ser humano que já não é mais humano. 
No cinema da primeira metade do século XX, foram dois os principais filmes (não pornográficos, mas de horror) que trataram do zumbi haitiano: White zombie ${ }^{15}$, de 1931 e I walked with a zombie ${ }^{16}$, de 1943 (RUSSEL, 2010). White zombie narra a estória de um rico colono que, ao se apaixonar por uma garota estrangeira já comprometida, pede ajuda a um feiticeiro e senhor de engenho local (interpretado por Bela Lugosi) para possuir a jovem. A solução oferecida é transformá-la em um zumbi. Desta ideia vem toda a força do terror proposto pelo filme: uma mulher branca da elite sócio econômica norte-americana zumbificada como os negros miseráveis trabalhadores das plantações haitianas, conforme analisa Bishop (2008). De maneira menos simplória e com uma discussão de fundo bem mais elaborada, I walked with a zombie fala sobre uma jovem enfermeira que vai trabalhar em uma ilha do Caribe cuidando da esposa de seu chefe, uma mulher que vive constantemente em um estado próximo ao sonambulismo. Ao conhecer as crenças locais, em especial os ritos vudus, a enfermeira passa a questionar os limites da ciência e da razão ocidentais (RUSSEL, 2010), tentando inclusive levar sua paciente para se submeter a um tratamento religioso vuduísta.

Ambos os filmes (mas principalmente o primeiro) espetacularizaram para as grandes audiências cinematográficas um monstro originado dos países colonizados do Novo Mundo, insinuando que a "barbárie nativa" dos povos subalternizados era uma ameaça real e constante. Em seu artigo sobre White zombie, Bishop (2008, p. 141) afirma: "em outras palavras, o verdadeiro horror nestes filmes está na perspectiva de um ocidental tornando-se dominado, subjugado e efetivamente 'colonizado' por um nativo pagão".

Ora, nos dois filmes, e bem de acordo com o resquício de espírito colonial que os anima, a sexualização da raça e a racialização do sexo é o pano de fundo de tais obras. Seja no desregramento sexual dos/as negros/as nativos/as ou na ameaça do corpo colonizador branco ser violado ou seduzido pelos costumes "exóticos", "bárbaros" e eroticamente permissivos, o controle sexual e o poder sobre o corpo da mulher "civilizada" e de sua feminilidade são algumas das temáticas principais (como a tal zumbi branca do título).

Mesmo com a figura do novo zumbi contemporâneo, o cadáver decomposto e agressivo, vários filmes não classificados como pornográficos, mas relacionando-o à temática da sexualidade, e mesmo do amor, foram feitos em muitos países, seja sob uma ótica cômica, política ou mesmo Queer (ou todas estas referências juntas). Podemos citar Nudist colony of the dead (Mark Pirro, EUA, 1991); Graveyard alive (Elza Kephart, Canadá, 2003) - comédia feminista onde uma enfermeira que torna-se zumbi começa a comer os homens que a perturbam; As strippers zumbi (Jay Lee, EUA, 2008) que tem como protagonista uma das grandes atrizes pornôs americanas da década de 90 , Jenna Jameson; Os amores de um zumbi (Arnold Antonin, Haiti, 2009) - filme romântico, cômico e político que fala sobre um zumbi que volta à vida por amor e

\footnotetext{
15 White zombie (Victor Halperin, EUA, 1931).

${ }^{16}$ I walked with a zombie (Jacques Tourneur, EUA, 1943).
} 
saudades de sua amante, além de retomar o tema do zumbi escravo haitiano; e os filmes do importante diretor queer canadense Bruce Labruce, Otto; or, up with dead people (Canadál Alemanha, 2008) ${ }^{17}$ e L.A. zombie (Alemanha/ EUA, 2010) - discutindo as conexões entre arte, sexo, morte e prazer como possíveis transgressões políticas, ambos com cenas de sexo "explícito".

Existem também vários filmes eróticos japoneses que tratam da relação entre sexo e zumbis. São produções do estilo pinku eiga, ou seja, próximas do que o Ocidente classifica como soft-core, onde as práticas sexuais são mais insinuadas do que explícitas, embora haja muitas cenas de nudez (predominantemente feminina). Muitas destas obras possuem uma forte influência da estética do grotesco, em trabalhos conhecidos neste país como eroguro (união das palavras em inglês erotic e grotesque) e são um exemplo claro do grotesco cômico, onde a monstruosidade, o baixo corporal e a escatologia visam mais o riso do que o medo, mais o cômico do que o sinistro, mas quase sempre evocando o nojento. Exemplo disso são os filmes Big tits zombie (Takao Nakano, Japão, 2010); Zombie ass - toilet of the dead (Noboro Iguchi, Japão, 2011) e Rape zombie: luxúria dos mortos 1, 2 e 3. (Naoyuki Tomomatsu, Japão, 2012, 2013 e 2013 respectivamente).

No campo específico da pornografia, existem filmes com zumbis e paródias deste gênero (tanto no mainstream hardcore, soft-core e alternativos) desde pelo menos a década de 70 do século XX. Se pensarmos a pornografia, ela mesmo como um gênero zumbi, ou seja, que se alimenta de outros gêneros artísticos, principalmente através da paródia, temos então uma longa lista tanto de filmes pornôs com zumbis quanto de filmes pornôs como zumbis. Vejamos alguns exemplos: I porno zombi (1977); Noites eróticas dos mortos-vivos (Joe D'Amato, EUA, 1980) - paródia de A noite dos mortosvivos, de George Romero; Nympho zombie coeds (1993); Queen of the porno zombies (1993); Re-penetrator (EUA, 2005) ${ }^{18}$ - paródia de Re-animator (Stuart Gordon, EUA, 1985); Back from the dead 1, 2 e 3 (2006); Monster tit sex zombies (2008); Dawna of the dead (2008) - paródia de Dawn of the dead, versão original também de Romero (EUA, 1978) e refilmado por Zack Snyder (EUA, 2004); Alco zombies (2009); I can't believe I fucked a zombie (2011); Zombies calientes del Getafe (2011); Beyond fucked: a zombie odyssey (2013) e Walking dead: a hardcore parody (2013) - como o título assume, paródia da série de televisão The walking dead (criador: Frank Darabond, EUA, 2010).

Se na pornografia a estética do grotesco encontra um vasto campo onde se desenvolver, através de imagens que priorizam um "mundo às avessas" - onde a lógica de um imaginado sexo desregrado e festivo predomina sobre a do trabalho cotidiano e cansativo; onde o foco da individualidade é menos o rosto e mais os genitais ou o ânus, e os closes nas protuberâncias e orifícios corporais são quase a regra visual -, nos pornôs com zumbis unem-se a estes elementos as cenas e figuras associadas à morte, à violência, ao putrefato e ao, literalmente, "visceral interior do organismo". Unindo sexo e horror, estas obras encontram ampla expressão do riso paródico e da deformidade de um pressuposto estético de corpo e sexo "belos".

\footnotetext{
${ }^{17}$ Para uma análise deste filme, ver Oliveira, 2009.

${ }^{18}$ Não encontrei a referência completa de todos os títulos: diretor, país, ano de lançamento. Muitas destas referências foram tiradas do site Internet Adult Film Database: http://www.iafd.com/
} 
O erotismo do zumbi envolve um striptease do corpo enquanto ele é violentamente aberto para as mãos e bocas de uma horda anônima. No banquete zumbi o corpo é despossuído não só de suas roupas, mas também de sua pele. Obscenamente aberto ao olhar, o tema do banquete zumbi é a metáfora visual final para a perda do auto-controle. O corpo está aberto ao olhar, suas cavidades interiores exibidas no auge de sua vida, enquanto a horda literalmente entra dentro e consome o corpo vivo (RUTHERFORD, 2013, p. 59) ${ }^{19}$.

Ora, da mesma forma, Mary Russo (2000) já mostrou como, do ponto de vista de uma cultura masculina, o corpo da mulher e a feminilidade são sempre vistas como algo grotesco em si, pois pressupõem uma deformação de um modelo "original", o corpo do homem e a masculinidade. Neste sentido, a própria estética do grotesco revela sua não neutralidade e sua associação a uma tradicional posição de poder, seja em matéria de gênero, sexualidade, raça, classe ou outros marcadores de diferença. Afinal, algo (ou alguém) é grotesco e "deformado" segundo a visão estética e os valores de qual grupo?

Neste sentido, talvez seja interessante pensar o filme pornográfico mainstream Porn of the dead - o "pornô dos mortos" (Rob Rotten, EUA, 2006). O título já é uma referência paródica à série de filmes de zumbis de Romero, em que quase todos terminam com a expressão "dos mortos" no título: Despertar dos mortos (1978), Dia dos mortos (1985), Terra dos mortos (2005), Diário dos mortos (2007) e Ilha dos mortos (2009). Rob Rotten (Rob Podre, o nome artístico do diretor) possui um histórico de filmes com a mistura entre pornô e horror, como $O$ Massacre do vibrador elétrico (EUA, 2006), paródia de O Massacre da serra elétrica (Tob Hoper, EUA, 1974, e refilmagem de Marcus Nispel, EUA, 2003), um dos grandes clássicos do cinema de sangue e violência explícita.

O início de Porn of the dead promete um desenvolvimento digno dos melhores filmes de zumbis: em um clima nublado e numa estrada vazia, uma garota zumbi, com andar lento e irregular, toda ensanguentada, perambula como sonâmbula pelo acostamento - tudo com uma trilha sonora pesada e imagem granulada, dando a impressão de algo sujo e abandonado. Um carro a acompanha lentamente e depois estaciona na estrada. De dentro dele, sai um homem usando luvas grossas de borracha e máscara protegendo as vias respiratórias. Ele examina os reflexos dela e não há reação nenhuma. Cuidadosamente, o homem a conduz para dentro do carro e a leva embora.

Esta introdução dura aproximadamente 2 minutos. Em seguida vem a apresentação do filme com os créditos, mostrando cenas de violência, sangue, blasfêmias com a religião cristã e, claro, sexo explícito. Logo após, a continuação da introdução que, rapidamente, se transforma em uma cena de sexo tradicional e comum aos filmes pornôs maistream: o homem que recolheu a garota zumbi faz sexo (entendase principalmente penetração do pênis) com ela. Ao final, quando depois de satisfeito sexualmente o sujeito vai esquartejá-la, ela o ataca, devora seu pênis e o mata. As outras cenas do filme, sem relação umas com as outras, seguem o mesmo tipo de roteiro, alterando apenas se a personagem do zumbi é um homem ou uma mulher, com um detalhe: todos os zumbis femininos, ao final da transa, devoram o pênis dos homens, que gritam de desespero e dor. Os zumbis homens não matam as mulheres (embora alguns tentem isso), apenas o contrário acontece.

\footnotetext{
${ }^{19}$ Todas as traduções deste artigo são do autor.
} 
Stephen Harper (2003), em seu artigo sobre a representação das mulheres nos filmes sobre zumbis de Romero (não pornôs, mas de horror), percebe o quanto a figura feminina vai adquirindo autonomia, liderança e um protagonismo cada vez maior na primeira trilogia do autor, da mesma maneira em que a diferença entre os humanos e os cadáveres ambulantes fica cada vez menor nestas obras. Isso acontece com muitos dos filmes deste gênero a partir do fim da década de 80. Inclusive na refilmagem de $A$ Noite dos mortos-vivos (Tom Savini, EUA, 1990), cujo diretor já havia trabalhado com Romero em seus filmes anteriores, esta importância das personagens ditas "subalternas" fica patente, em uma das mensagens políticas mais explícitas deste gênero: "Em termos gerais, os zumbis de Romero no remake de 'Noite [dos mortos-vivos]', não são, como eram na versão original, apenas inimigos dos seres humanos; em vez disso, tornaram-se significantes flutuantes da opressão sexual e racial” (Harper, 2003, sem página).

Que contradição histórica curiosa: enquanto os filmes de horror com zumbis (vistos tradicionalmente como violentos e sem conteúdo crítico) passam a denunciar a opressão de grupos marginalizados através do "horror artístico" (HARPER, 2003; LOUDERMILK, 2003; PEAK, 2010), a pornografia mainstream (que muitas vezes se apresenta como libertária), reforça estereótipos de raça e gênero, mesmo quando os zumbis é que são protagonistas de tais produções.

Apesar de Porn of the dead receber críticas boas de seu meio profissional ${ }^{20} \mathrm{e}$ desta visão quase pró-zumbis fêmeas, o filme ainda carrega muito da heteronormatividade e mantém todos os clichês da pornografia tradicional. Apesar de ele investir pesado na estética grotesca, tanto sinistra como cômica (pois a maquiagem das/os atrizes/atores vai saindo durante a prática sexual e alguns cenários são assumidamente pobres), ajudando a causar o efeito de algo grosseiro e agressivo, a lógica do corpo masculino subjugando o feminino (e, no máximo, este se revolta violentamente) e a ideia de que prática sexual é quase que exclusivamente penetração permanecem inalteradas. Neste sentido, voltamos ao paradoxo da paródia: a crítica que a paródia prenuncia (neste caso, sobre os filmes de zumbi) parece não se realizar completamente, mas, ao mesmo tempo, pelo exagero da lógica do sexo heteronormativo e possessivo pode-se causar um distanciamento crítico com relação à própria pornografia mainstream.

\footnotetext{
As transgressões da paródia permanecem, em última análise, autorizadas - autorizadas pela própria norma que procura subverter. Mesmo ao escarnecer, a paródia reforça; em termos formais, inscreve as convenções escarnecidas em si mesma, garantindo, consequentemente, a sua existência continuada. (HUTCHEON apud ALAVARCE, 2009, p. 68).
}

E nesse momento a pornografia mainstream realmente encarna um morto-vivo: reafirma todos os conceitos tradicionais, heteronormativos e sexistas de séculos. Desta forma, ideias que já poderiam (ou deveriam) estar mortas e enterradas mostram-se vivas e atuantes em muitas destas produções. Por ter como fonte principal de alimento os outros gêneros (artísticos) e atualizar visões de gênero (sexual) que se enquadrariam melhor em um mundo passado, talvez estas obras pornográficas não apenas apresentem

\footnotetext{
${ }^{20}$ http://www.avn.com/movies/65793.html
} 
mortos-vivos em suas produções, um pornô com zumbis, mas elas mesmas sejam um morto-vivo, um tipo de pornô como um zumbi.

Por outro lado, este reiteração irrefletida de normas encarnadas em práticas, gestos e comportamentos também acusa a todo o momento as fissuras e falhas destas normas. A literal incorporação de ideais, orientando e materializando corpos, sujeitos e experiências inteligíveis, é o que a filósofa estadunidense Judith Butler chama de "performatividade", que não se confunde com a noção de interpretação artística. Segundo a autora,

performatividade é reiterar ou repetir as normas mediante as quais nos constituímos: não se trata da fabricação radical de um sujeito sexuado genericamente. É uma repetição obrigatória de normas anteriores que constituem o sujeito, normas que não podem ser descartadas por vontade própria. São normas que configuram, animam e delimitam ao sujeito de gênero e que são também os recursos a partir dos quais se forja a resistência, a subversão e o deslocamento. (BUTLER, 2002, p. 64).

É desta forma então que a paródia pode se tornar uma política crítica, como já apontado pela mesma autora (BUTLER, 2003): a paródia explicita nossa performatividade mostrando que, no limite, não existe um original a ser copiado (ou parodiado), e mesmo os comportamentos, atitudes e subjetividades vistas como mais "naturais" não passam de uma estilização, uma frágil tentativa de incorporar ideais que são apenas repetição, sem um original primeiro ou último e em constante necessidade de reafirmação. Neste sentido, toda paródia provoca um tipo de identificação, causando reflexão e estimulando alguma mudança, mesmo que seja pelo incômodo, ridículo ou agressivo, que ela provoca. "Nos filmes de mortos-vivos, o refrão 'eles somos nós' reconhece não apenas a comunhão dos zumbis com todos os humanos mas, também, e mais especificamente, a identificação dos zumbis com os grupos explorados de seres humanos" (HARPER, 2003).

Neste sentido, seja na pornografia mainstream, muitas vezes com sua reiteração de estereótipos racistas e sexistas, nas obras apresentando mortos-vivos com suas mentes e corpos deteriorados, violados e violadores, ou através tanto do horror artístico quanto do horror cotidiano, parece não restar dúvidas: "eles somos nós".

\section{REFERÊNCIAS}

ABREU, Nuno César. O Olhar pornô. Campinas: Mercado das Letras, 1996.

ALAVARCE, CS. A Ironia e suas refrações: um estudo sobre a dissonância na paródia e no riso [online]. São Paulo: Editora UNESP; São Paulo: Cultura Acadêmica, 2009. Disponível em: http://static.scielo.org/scielobooks/5dcq3/pdf/alavarce-9788579830259.pdf

AUGUSTO, Sérgio. Este mundo é um pandeiro. São Paulo: Companhia das Letras, 1989.

BAKHTIN, Mikhail. Problemas da poética de Dostoievski. Rio de Janeiro: Forense, 1981.

. A Cultura popular na Idade Média e no Renascimento. São Paulo: Hucitec/ UNB, 2010.

BISHOP, Kyle. The sub-subaltern monster: imperialist hegemony and the cinematic voodoo zombie. The Journal of American Culture, v. 31, n. 2, maio 2008.

BUTLER, Judith. Problemas de gênero: feminismo e subversão da identidade. Rio de Janeiro: Civilização Brasileira, 2003. 
BUTLER, Judith. Críticamente subversiva. In: JIMÉNEZ, Rafael M. Mérida (org.). Sexualidades transgressoras: una antologia de estúdios queer. Barcelona: Icaria Editorial, 2002.

CALMET, Auguste. Informe sobre os vampiros. In: Histórias de vampiros. São Paulo: Hemus, s/d.

CARROLL, Noël, A Filosofia do horror. Campinas: Papirus, 1999.

DEL PRIORE, Mary. Esquecidos por Deus. São Paulo: Companhia das Letras, 2000.

DIAS, Ângela; LYRA, Pedro. Paródia: introdução. Revista Tempo Brasileiro: Sobre a paródia. Rio de Janeiro, n.62, jul.-set. 1980.

DIAZ-BENÍTEZ, Maria Elvira. Nas redes do sexo. Rio de Janeiro, Jorge Zahar, 2010.

DREZNER, Daniel W. Theories of international politics and zombies. Princeton: Princeton University Press, 2011.

ELIADE, Mircea. As mitologias da morte: uma introdução. In: Ocultismo, bruxaria e correntes culturais. Belo Horizonte: Interlivros, 1979.

. O sagrado e o profano. São Paulo: Martins Fontes, 1992.

GUREVICH, Aaron. Bakhtin e sua Teoria do Carnaval. In: BREMMER, Jan; ROODENBURG, Herman (orgs.). Uma história cultural do humor. Rio de Janeiro: Record, 2000.

HARPER, S. ‘They're us': representations of women in George Romero's 'Living Dead' series.

Intensities: the Journal of Cult Media, v.3, Winter 2003. Disponível em:

http://intensitiescultmedia.files.wordpress.com/2012/12/harper-theyre-us.pdf

HUGO, Victor. Do grotesco e do sublime: Prefácio de Cromwell. São Paulo: Perspectiva, 2002.

HUTCHEON, Linda. La política de la parodia posmoderna. Criterios, edición especial de homenaje a Bajtín. Julio, 1993.

KAYSER, Wolfgang. O Grotesco. São Paulo: Perspectiva, 1986.

LANDA, María Inés; LEITE JR, Jorge; TORRANO, Andrea. Gestão da monstruosidade: os corpos do obeso e do zumbi. In BONELLI, Maria da Gloria; LANDA, Martha Diaz Villegas de. Sociologia e mudança social no Brasil e na Argentina. São Carlos: CAPES / Compacta Gráfica e Editora, 2013 Disponível em: http://www.ppgs.ufscar.br/SociologiaeMudancaSocialnoBrasilenaArgentina.pdf LOUDERMILK, A. Eating "dawn" in the dark: zombie desire and commodified identity in George Romero's "Dawn of the dead". Journal of consumer culture, 2003, v. 3, n. 83. Disponível em: http://joc.sagepub.com/content/3/1/83. Acesso em 10/04/2013.

MORAES, Eliane Robert. O Corpo impossível. São Paulo: Iluminuras, 2010.

OLIVEIRA, Leonardo Davino de. Bruce LaBruce e a morte depois da morte. Bagoas Estudos gays: gêneros e sexualidades, Natal, n. 6, 2011, p. 315-326. Disponível em: http://incubadora.ufrn.br/index.php/Bagoas/article/view/453/377. Acesso em: 14 jan. 2014.

ORTEGA, Francisco. O corpo transparente: visualização médica e cultura popular no século XX. Hist. cienc. saude-Manguinhos. Rio de Janeiro, 2013. Disponível em:

http://www.scielo.br/scielo.php.script=sci_arttext\&pid=S0104-59702006000500006\&lng=en\&nrm=iso

PEAKE, Bryce. He is dead, and he is continuing to die: A Feminist psycho-semiotic reflection on men's embodiment of metaphor in a Toronto zombie walk. Journal of Contemporary Anthropology. Jan 2010, v.1, n.1, p 49-71. Disponível em:

http://docs.lib.purdue.edu/cgi/viewcontent.cgi?article=1003\&context=jca

RUSSEL, Jamie. Zumbis: o livro dos mortos. São Paulo: Leya Cult, 2010.

RUSSO, Mary. O Grotesco feminino. Rio de Janeiro: Rocco, 2000.

RUTHERFORD, Jennifer. Zombies. New York, Routledge, 2013.

SAEZ, Javier. El macho vulnerable: pornografia y sadomasoquismo. 2003. Disponível em: http://www.hartza.com/fist.htm

SANT'ANNA, Affonso Romano de. Paródia, paráfrase \& cia. São Paulo: Ática, 1988.

SEABROOK, William B. A Ilha da magia. São Paulo: Hemus, s/d.

SODRÉ, Muniz; PAIVA, Raquel. O Império do grotesco. Rio de Janeiro: Maud, 2002.

WILLIAMS, Linda. Skin flicks on the racial border: pornography, exploitation, and interracial lust. In: WILLIAMS, Linda (Ed.). Porn studies. London: Duke University Press, 2004. 
Recebido em 04/08/2014. Aprovado em 09/11/2014.

Title: Is pornography a living-dead?

Abstract: One of the most notable characteristics of the audiovisual genre known as pornography is maybe its infinite ability for parody. From animated cartoons to songs to literary works to movie productions, the pornographic genre seems to feed mainly off other kinds of "genres", both artistic and sexual (gender). Thus, by taking advantage of the media success of one of the most broadcast contemporary monsters, the zombie, pornography also incorporates this curious being, which represents a dead person who insists on acting in the world of the living. The aim of this work is to reflect about porn movies with zombies, investigating how much of pornography itself could be seen as a genre that lives off devouring other (artistic) genres and, mainly, how much mainstream pornography replicates traditional gender roles that could have been dead and buried in history already, but which insist on acting in our quotidian lives.

Keywords: Pornography. Gender. Horror. Grotesque. Zombies. 
